\title{
Study and rehabilitation of some endemic Argentinian taxa in the genus Viola L. (Violaceae), and lectotypification of a Peruvian species
}

\section{Estudio y rehabilitación de algunos taxones endémicos argentinos en el género Viola L. (Violaceae), y lectotipificación de una especie peruana}

\author{
John M. Watson \& Ana R. Flores \\ Casilla 161, Los Andes, Chile. \\ john.anita.watson@gmail.com
}

\begin{abstract}
Taxa of Viola sect. Andinium are detailed. W. Becker described new violas collected by H.F. Comber in 1925-1926. Sixty years later R.A. Rossow treated them in Flora Patagonica. His views have subsequently been followed in Argentina and influence taxonomic decisions taken there. Three of Comber's species not included or accepted by Rossow are rehabilitated. $V$. comberi, synonymised by him, differs critically from all related taxa in its unique set of characters. He placed $V$. cotyledon subsp. lologensis in synonymy under $V$. dasyphylla. As it combines equally defining features of that species and $V$. cotyledon, it is elevated to full species rank here. V. escondidaensis, a distinct taxon with no close relatives, was omitted from Flora Patagonica. It may be found incorrectly synonymised under $V$. fluehmannii. V. nobilis, as also mentioned comparatively in the Conclusion, is lectotypified.
\end{abstract}

Keywords: Adaptation, Andean, Northern Patagonia, rarity, taxonomic boundaries, type specimens, untraceable taxa.

\begin{abstract}
RESUMEN
Se examinan taxones de Viola de la sección Andinium. W. Becker describió nuevas violas recolectadas por H.F. Comber en 1925-1926. Sesenta años más tarde R.A. Rossow las trata en Flora Patagónica. Sus puntos de vista han sido posteriormente seguidos en Argentina y han influido en las decisiones taxonómicas tomadas allá. Se rehabilitan tres de las especies de Comber que no fueron incluidas o aceptadas por Rossow. V. comberi, que fue sinonimizada por él, difiere críticamente de todos los taxones relacionados por un conjunto de caracteres únicos. El pone a $V$. cotyledon subsp. lologensis como sinónimo de $V$. dasyphylla. Porque combina por igual características de esta especie y $V$. cotyledon, se eleva a rango de especie. $V$. escondidaensis, un taxón distinto sin parientes cercanos, fue omitido de Flora Patagónica. Esta puede ser encontrada incorrectamente como sinónimo de $V$. fluehmannii. V. nobilis, como también se menciona comparativamente en la Conclusión, se lectotipifica.
\end{abstract}

Palabras clave: Adaptación, andino, Patagonia del norte, taxones escasos, divisiones taxonómicas, especimenes tipo, taxones extraviados.

\section{INTRODUCTION}

Viola taxa considered here belong to the substantial sect. Andinium W. Becker (1925). At present the section numbers ca. 114 species (Watson \& Flores, H.E. Ballard unpubl.). They occur almost continuously along the Andean-Pacific sector between the equator and $48^{\circ} \mathrm{S}$. Their main centre of distribution is the central and southern temperate cordilleras of Argentina and Chile between $30^{\circ} \mathrm{S}$ and $41^{\circ} \mathrm{S}$, with secondary centres in NW Argentina and Peru. The three taxa profiled here inhabit the southern sector of the main centre of distribution, between $37^{\circ} \mathrm{S}$ and $41^{\circ} \mathrm{S}$ (Fig.1).
Section Andinium comprises dwarf, mainly acaulous herbaceous annuals and chamaephytes. Many are littleknown, several having been collected once only, and without subsequent rediscovery. Although diverse in vegetative form, the section is dominated by caudiculate rosulate taxa (Reiche 1893, Becker 1925, Watson \& Flores 2007). Of the three species described below two are rosulate, while the third, Viola escondidaensis W.Becker, bears small ephemeral seasonal rosettes at the tips of its stems.

Infraspecific elements have been published for sect. Andinium, and some may still be found in general taxonomic catalogues (e.g. Marticorena \& Quezada 1985). However, 
few -if any- are recognised by current specialists. The section has always largely comprised taxa at full species rank, a classification level now close to all-embracing. Morphological discontinuities are not uncommonly minimal and even single, but always precise and frequently supported by geographical separation.

Between 1925 and 1927 the professional English gardener and nurseryman, Harold Comber, was funded by a British consortium to bring back plants new to horticulture from northern Andean Patagonia (Coats 1970, Del Vitto et al. 1998: 198). Most of his work took place in Argentina. He also made comprehensive voucher collections for the Royal Botanic Gardens, Kew. These included a number of Viola species.

Wilhelm Becker of Berlin-Dahlem, the leading Viola authority of his day and foremost specialist to date on sect. Andinium, determined Comber's 1925 and 1926 Patagonian collections of the genus. He described nine as new taxa of the section in Bulletin of Miscellaneous Information, Royal Botanic Gardens, Kew [now Kew Bulletin] (Becker 1928).

Of Comber's novelties, two at infraspecific and one at specific level are agreed as synonyms by all modern specialists. Several others are universally accepted, but those considered here were either not entered, or were listed as synonyms in Flora Patagonica (Rossow 1988). Nor are they currently recognised by national authorities in Argentina (Xifreda \& Sanso 1999, Sanso et al. 2008). Reasons for affirming their acceptance, and also for raising one to species rank, are presented here.

Viola nobilis W. Becker is included below as one of several in sect. Andinum which are only known from their type gatherings.

\section{MATERIALS AND METHODS}

Comber's types and his other Viola specimens were examined in 1971 and 1995 at the Royal Botanic Gardens, Kew, herbarium $(\mathrm{K})$. There are no known duplicates elsewhere. A copy of the collector's limited edition field notes (Comber 1928) was also scrutinized.

In addition, personal information from his hand-written memoranda and maps was made available by his daughter, Mary Comber-Miles.

Several field searches were conducted in the 1990s for all three species described below. Further information and observations have been added by J. \& H. Birks, K. Blaxland, P.J. Erskine, M. Ferreyra, M. Millahuinca, M. \& A. Sheader and D. \& A. Wraight. Much relevant unpublished field information was imparted by R.A. Rossow in 1993, who also provided a duplicate voucher specimen of $V$. escondidaensis.

\section{RESULTS}

Viola comberi W. Becker, Bull. Misc. Inform. Kew 1928: 136.

TYPE: “Argentina, 40S:" Prov. Neuquén, "Cerro Colohuincul, between San Martín de los Andes and Lago Huechulafquen, 2100 m., Dec.1926, H.F Comber 882; Only one plant seen. Flowers yellow, striped with brown lines." (Holotype K!).

Four of Comber's discoveries originate from Cerro Colohuincul $(2,146 \mathrm{~m})$ immediately south of Lago Curruhue Chico (Comber 1928) (Fig. 1): Viola squamulosa W. Becker - a synonym of Viola sacculus Skottsb. (Fig. 2), Viola dasyphylla W. Becker (Figs. 3 \& 4), Viola coronifera W. Becker (Fig. 5) and V. comberi. That sprawling mountain massif, previously unexplored floristically, may be found identified alternatively as Cerro Aseret, one of its subordinate peaks to the west. All those species, except $V$. comberi, are known from other localities. As noted, Comber encountered one plant only, the type.

After Comber, no further floristic investigation of the upper mountain took place until 1988. Between that year and the present it has been explored on various occasions by small groups and individuals from Europe with botanical interests (e.g. Erskine 1994, Ecological and Environmental Change Research Group undated, Zwienen 2011). The principle objective of these visits was always the violas. Regional Argentinian botanists have now certainly explored high on Cerro Colohuincul as well (Ferreyra et al. 2006). All the aforementioned encountered $V$. coronifera, but none has reported any plant recognisable as $V$. comberi.

Becker's protologues (1928), where Comber's field notes are cited, indicate clearly that $V$. coronifera and $V$. comberi are remarkably similar in general appearance. Both possess identical, tightly imbricated foliage with a circlet of upwardsfacing flowers crowning the flat rosette face (Fig. 5). Corollas are similar-sized and bright yellow to light orange, an uncommon coloration for perennials of the section. The solitary $V$. comberi rosette is smaller compared with $V$. coronifera. $V$. comberi corollas are described as densely veined with brown. However, occasional brown-veined or brown-tinged forms of $V$. coronifera are also known (pers. obs.). Unfortunately, it is not possible to deduce from a solitary specimen of $V$. comberi whether brown veining is a fixed or variable feature. Individuals with unmarked corollas would certainly be undistinguishable on sight from $V$. coronifera .

We have examined the only specimen of $V$. comberi superficially at Kew, and our observation confirms the information provided by Becker (1928).

Major critical dissimilarities between the two taxa are small and cryptic, but none-the-less significant and defining in the context of sect. Andinium. Comparative circumscriptions below as taken from Becker (1928) denote differences: 


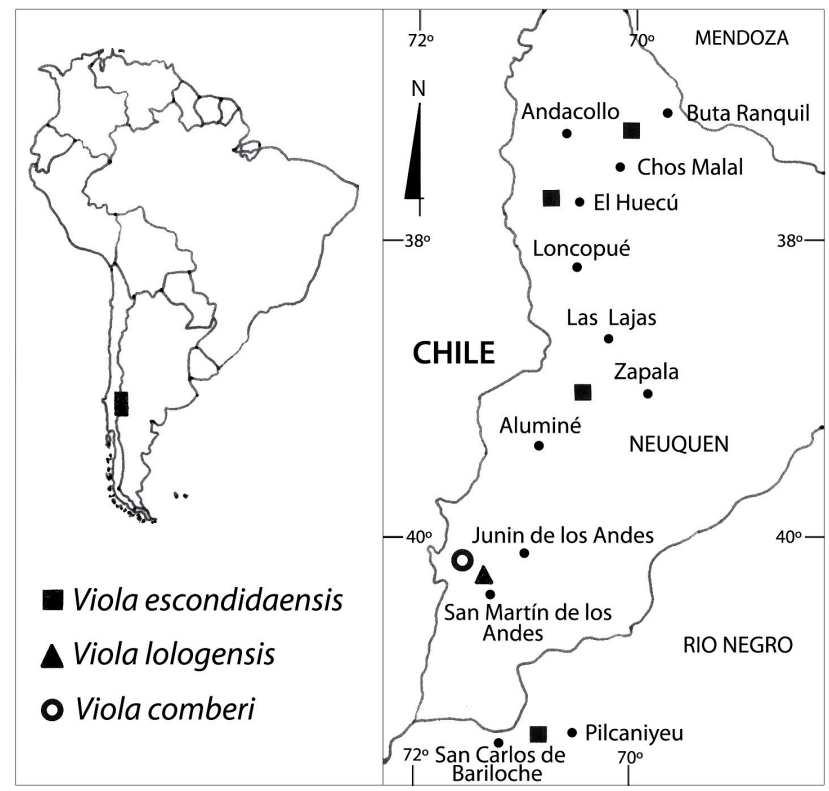

FIGURE 1. Geographical context of the overall distribution area of Comber's three violas under consideration (left). Individual distributions in Argentinian Patagonia of $V$. comberi, V. escondidaensis and V. lologensis (right).

FiguRA 1. Ubicación geográfica del área de distribución total de las tres violas de Comber estudiadas (izquierda). Distribuciones individuales de V. comberi, V. escondidaensis y V. lologensis en la Patagonia argentina (derecha).

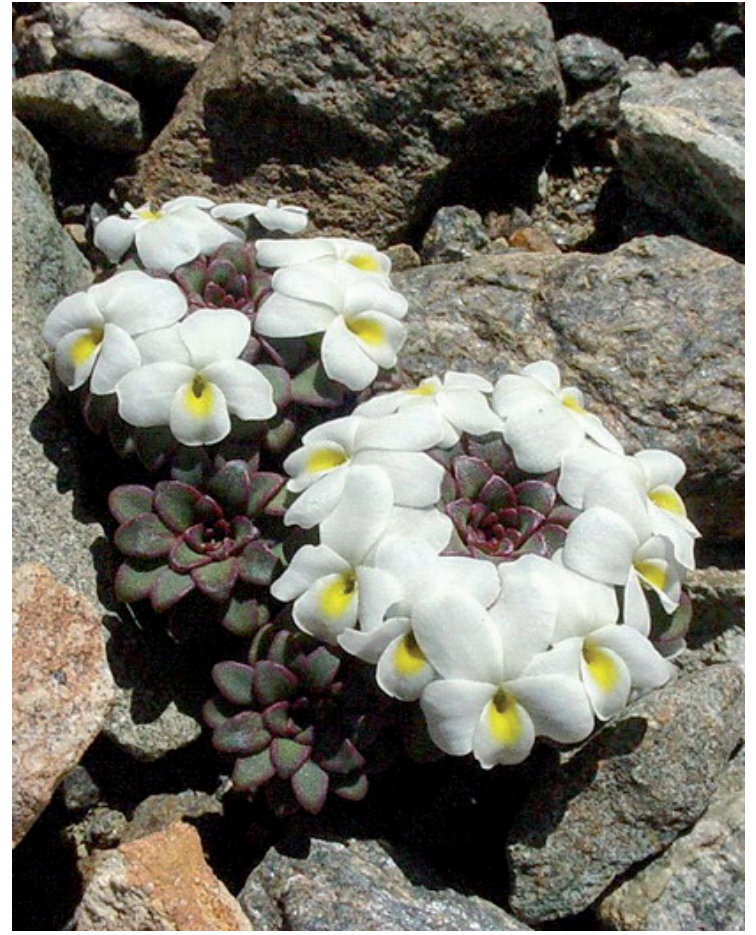

Figure 2. Viola sacculus Cerro Catedral, Río Negro, Argentina, December 2002 (Photo: Ana Flores).

Figura 2. Viola sacculus Cerro Catedral, Río Negro, Argentina, diciembre 2002 (Foto: Ana Flores).

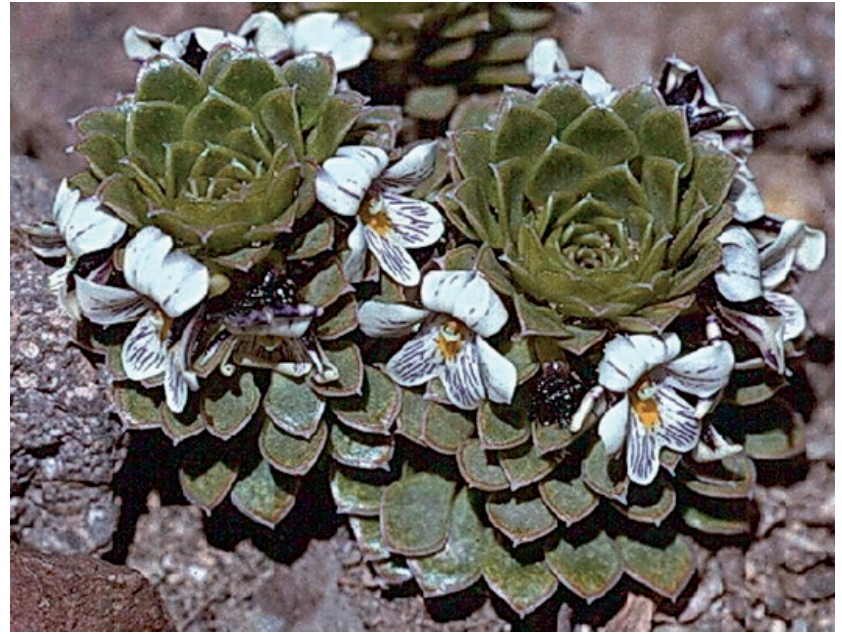

FIGURE 3. Viola dasyphylla displaying typical compact rosette form and black-viscid calyces. Cerro Chapelco, Neuquén, Argentina, January 1991 (Photo: John Watson).

Figura 3. Rosetas de Viola dasyphylla mostrando su típica forma compacta y sus cálices negro-viscosos. Cerro Chapelco, Neuquén, Argentina, enero 1991 (Foto: John Watson). 


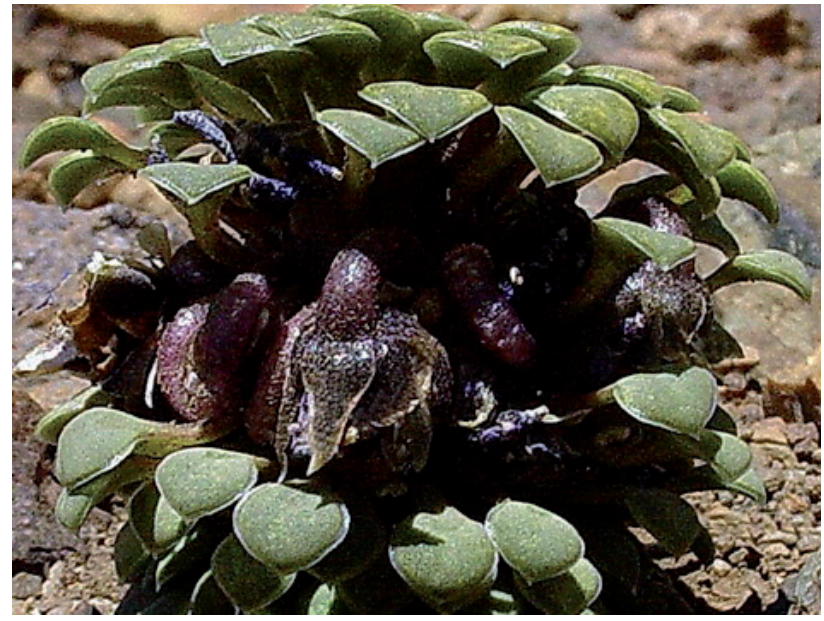

Figure 4. $V$. dasyphylla in early fruit, plainly exhibiting the characteristic dark calyces. Cerro Atravesada, Neuquén, Argentina, December 2007 (Photo: Ana Flores).

Figura 4. $V$. dasyphylla en fructificación temprana, exhibiendo claramente su distintivo cáliz oscuro. Cerro Atravesada, Neuquén, Argentina, diciembre 2007 (Foto: Ana Flores).

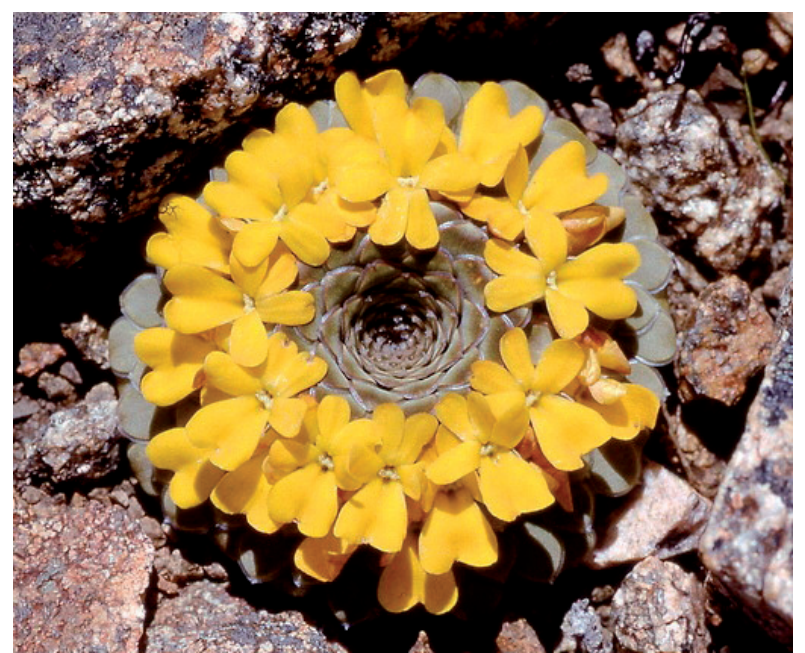

FIGURE 5. Viola coronifera, showing defining ring of upwardsfacing corollas on rosette face. Cerro Colohuincul, Neuquén, Argentina, December 1992 (Photo: John Watson).

FIGURA 5. Viola coronifera con las corolas hacia arriba sobre la roseta, formando un anillo definido. Cerro Colohuincul, Neuquén, Argentina, diciembre 1992 (Foto: John Watson).

\section{KeY to DISTINGUISH $V$. CORONIFERA AND $V$. COMBERI}

1. Sepals: $8 \mathrm{~mm}$ long. Spur about $1 \mathrm{~cm}$ long. Stamens not ciliate. Style crest: funnel-shaped, but with an opening girdling the front. V. coronifera

1'. Sepals: $5 \mathrm{~mm}$ long. Spur about $4 \mathrm{~mm}$ long. Stamens: densely ciliate. Style crest not funnel-shaped, but with two lateral horizontal down-curved lobes and a short median lobe directed to the rear...... V. comberi

Viola escondidaensis W. Becker, Bull. Misc. Inform. Kew 1928: 138 (Figs 6,7 \& 8)

TYPE: "Argentina, Valle Escondida, Territory of Neuquen, 1925-6, H.F. Comber 241; Perennial with underground stems. Flowers pale green with blue lines." (Holotype K!).

Icon.: A.R. Flores, Chagual 5: 35, fig. 3. 2007.

Dwarf, rhizomatous, perennial herb, pilose to glabrescent, spreading to $30 \mathrm{~cm}$ or more from stouter vertical central root by extensive subterranean system of sparsely branching, more or less horizontal, slender, stringy, fleshy-brittle, white runners, these at times emerging as decumbent, leafless ground-stems; foliate aerial tip suberect to erect, 5$15 \mathrm{~cm}$ high at anthesis. Aerial stem simple, ca 2-2.5 mm dia., subsucculent, sometimes blood-red (Fig. 6); internodes of fertile stems ca $2-5 \mathrm{~mm}$; upper stem and peduncles glabrous to pilose. Stipules absent. Mature leaves whitish green to greyish green, usually subpatent to suberect, 10-20 $\mathrm{x}$ 1.5-4 mm including pseudopetiole, reduced and sparse at base of stem, upper surface glabrous or with remote, minute hairs, lower surface glabrous to densely whitepilose, margin glabrous to ciliate; pseudopetiole ca 5-8 $\mathrm{mm}$ long, narrowing at base to ca $0.3-1 \mathrm{~mm}$ wide; blade oblanceolate- to subspathulate-cuneate, obtuse to acute and shortly apiculate. Flowers solitary from axil, numbering to about 10, congested with foliage at apex of shoot, white or pale green with yellow throat; lowermost petal only to all petals sparsely veined with pale blue-violet, or corolla densely veined deep violet overall. Peduncles equal to or often exceeding leaves, with two dark, linear-lanceolate, acute basal bracteoles, ca $1.5 \mathrm{~mm}$ long. Sepals lanceolate to ovate, more or less scabrid, acute, margins glabrous to sparsely ciliate. Apex of petals sometimes minutely suberose or crispate; upper petals $7-8 \mathrm{~mm}$, spathulate to oblong-spathulate, obtuse, recurved to strongly recurved, more or less revolute above, glabrous; lateral petals 7-8 $\mathrm{mm}$, spathulate, more or less revolute, obtuse to truncate, glabrous to weakly and sparsely pilose at base; lowermost petal 6-7 mm, elongate-pandurate, often channelled, deeply emarginate with two oblong, obtuse terminal lobes, bearded 
with two lateral lines of dense, pilose hairs at spur mouth; spur ca 2-3 mm. Stamens shortly pilose. Style geniculate, clavate above; style crest two somewhat divergent, narrow, back-turned lobes.

When corolla veining is dense and intense, it slightly saturates the surrounding tissues, also imparting a faint bluish background tinge to the petal tips (Fig. 6).

The above circumscription is an amended and expanded version of the original protologue (Becker 1928). It incorporates minor morphological traits found in the recently discovered populations described below. The northernmost population is mainly glabrous to glabrescent (Figs $6 \& 7$ ). However, no defining discontinuity has been recorded for any polymorphic character.

A later February collection (F\&W 10691) consists of juvenile sterile shoots $2-5 \mathrm{~cm}$ high, leaves dense-set, the apex distinctly subimbricate-rosulate.

Taxonomically remote $V$. escondidaensis bears no obvious resemblance to any other described species of sect. Andinium. Its status as a valid, distinct species, supported by the above description, is undeniable, and has never been doubted by the present authors (Watson 1994a, 1994b, Watson \& Flores 2007). It is currently known from four widely disjunct North Patagonian locations in Neuquén and Río Negro provinces, the northernmost being the Tromén

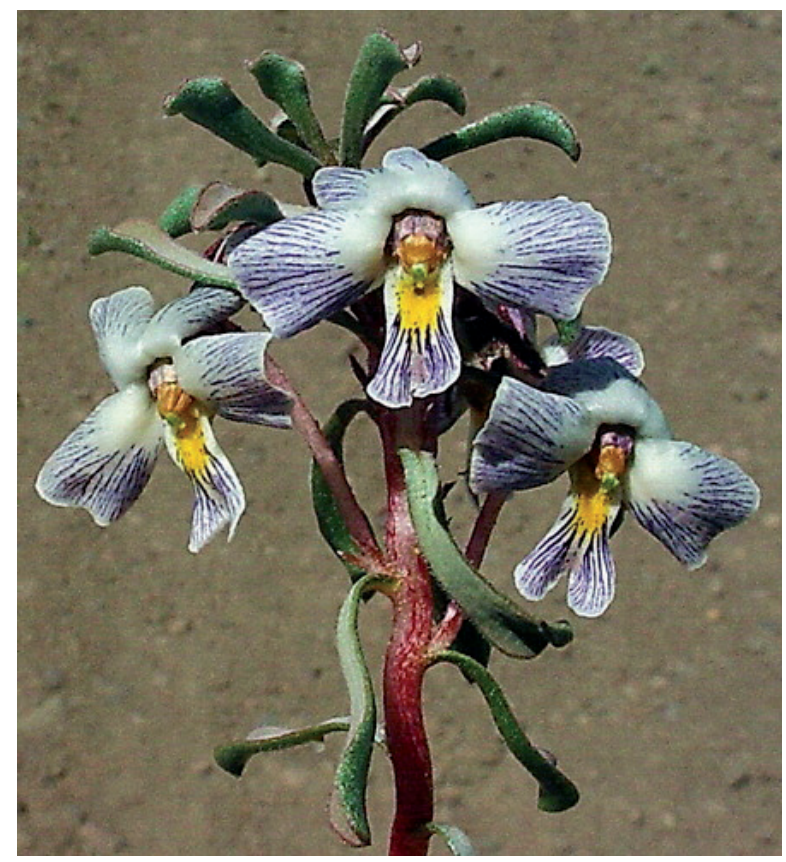

FIGURE 6. A heavily violet-veined, glabrescent individual of $V$. escondidaensis with red stems. Tromén Provincial Park, Neuquén, Argentina, November 2002 (Photo: Ana Flores).

Figura 6. Planta glabrescente individual de $V$. escondidaensis con venas fuertemente violetas en todos los pétalos, y tallos rojos. Parque Provincial Tromén, Neuquén, Argentina, noviembre 2002 (Foto: Ana Flores).
Provincial Wild Nature Park. Martin and Anna Sheader (in litt.) have very recently noticed on a photographic image what are undoubtedly sterile shoots of $V$. escondidaensis growing among Viola congesta Gillies ex Hook. \& Arn. This was recorded near El Huecú, to the north of Neuquén province, $65 \mathrm{~km}$ south of the Tromén area.

With the help of information provided by Comber's daughter the type site, Valle Escondida (sic), has been traced provisionally to ca $125 \mathrm{~km}$ further south still, on high ground west of Zapala, between roads RN13 and RN46 and northeast of Lago Aluminé. Another recent discovery (Fig. 8), the southernmost, was made by Marcela Ferreyra. It is situated in Río Negro Province at $41^{\circ} 07^{\prime} 21.33^{\prime \prime} \mathrm{S} ; 70^{\circ}$ 42'29.32' W near Pilcaniyeu, ca. $25 \mathrm{~km}$ due east of Lago Nahuel Huapi (M. \& A. Sheader in litt.). That places it ca. $260 \mathrm{~km}$ south of Valle Escondida. The longitudinal range of the species (Fig. 1) is therefore close to $450 \mathrm{~km}$.

Specimens examined: Argentina, Prov. Neuquén, Dept. Chos Malal, Parque Provincial Tromén, southern entrance, $37^{\circ} 10^{\prime} 30.60^{\prime \prime} \mathrm{S}, 70^{\circ} 10^{\prime} 05.88^{\prime \prime} \mathrm{W}, 1997-2000$ m.s.m. XII1992, Rossow et al. s.n. (as Flores \& Watson 7613) (Herb. Flores \& Watson); Ibid., 24-XII-2002, Flores \& Watson, 10632 (Herb. Flores \& Watson); Ibid., 05-II-2003, Flores \& Watson 10691 (Herb. Flores \& Watson).

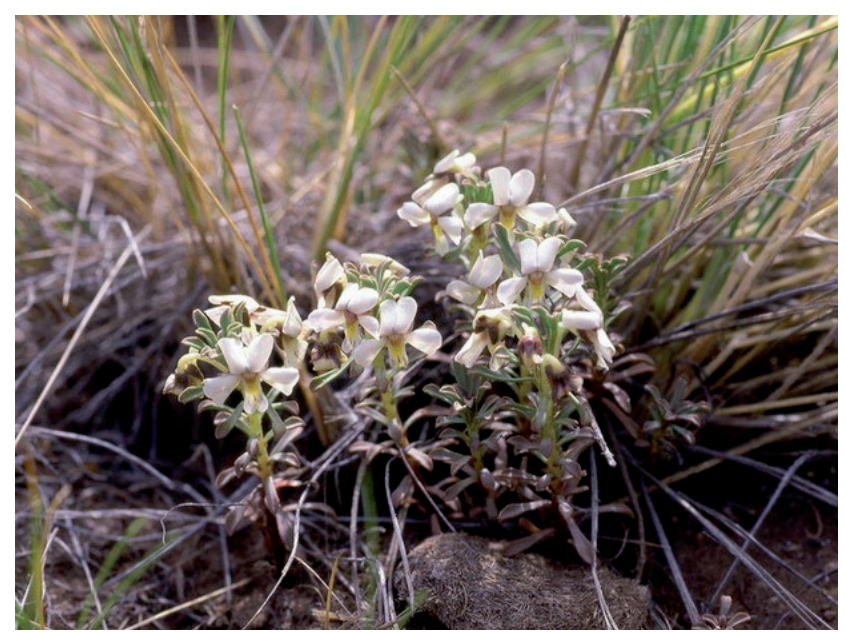

FiguRE 7. Bunchgrass habitat of glabrescent populations of Viola escondidaensis. Tromén Provincial Park, Neuquén, Argentina, December 2002 (Photo: John Watson).

Figura 7. Habitat coironal de las poblaciones glabrescentes de Viola escondidaensis. Parque Provincial Tromén, Neuquén, Argentina, diciembre 2002 (Foto: John Watson). 


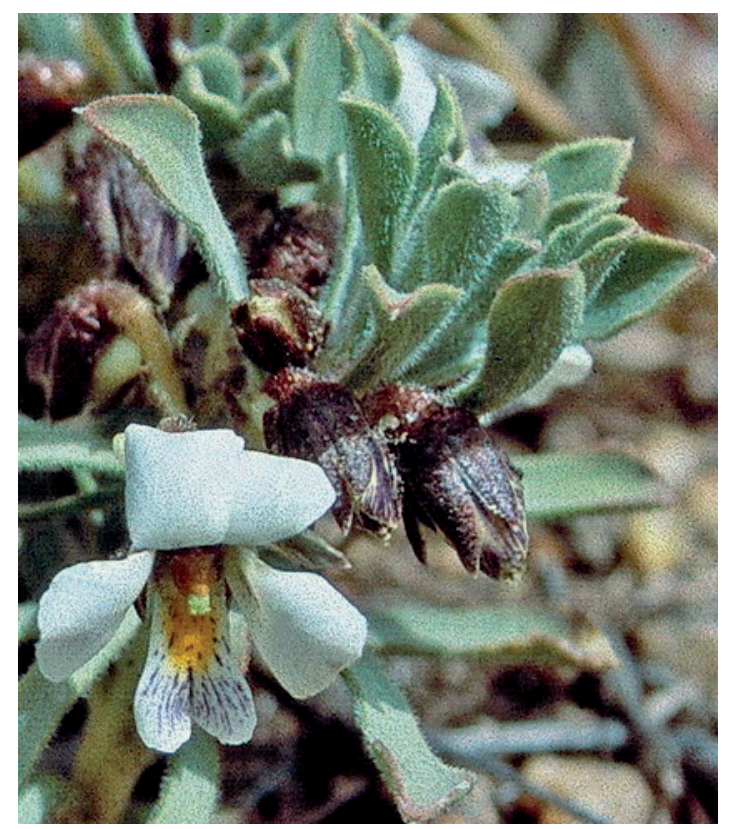

Figure 8. V. escondidaensis from population with white-pilose leaves. Pilcaniyeu, Río Negro, Argentina, December 2005 (Photo: Martin \& Anna Sheader).

Figura 8. V. escondidaensis de una población con sus hojas blanco-pilosas. Pilcaniyeu, Río Negro, Argentina, diciembre 2005 (Foto: Martin \& Anna Sheader).

Viola lologensis (W. Becker) J.M. Watson, stat. nov. (Fig. 9). Basionym: Viola cotyledon Ging. subsp. lologensis W. Becker, Bull. Misc. Inform. Kew 1928: 135 TYPE: "Argentina, $40^{\circ} \mathrm{S}$," Prov. Neuquén, "Vega Lolog, , 810 m, Dec. 1926, H.F. Comber 816; A long-rooted perennial from sandy stony places. Flowers white with violet lines and translucent margin.” (holotype K!).

Icon.: S. Clay, The present-day rock garden, plate 55 (lower). 1937.

In 1926 Comber made two gatherings of a Viola from sect. Andinium above Lago Lolog in Neuquén province, Argentina. Comber's nine new Viola taxa included the Lolog plant, which Becker (1928) judged to be a subspecies (subsp. lologensis) of $V$. cotyledon (Figs $10 \& 11$ ). In its type circumscription, he noted of the style crest: " 2 lateral pendulous lobes, 1 short lobe directed to the rear, therefore the same as typical $V$. cotyledon," However, such a style crest presents an outline no less comparable with the crest of $V$. dasyphylla (Rossow 1988). To that can be added the corolla description of the violas from Lolog: white flowers with violet or blue guide lines, which the reproduced photograph from Clay (1937) (Fig. 9) clearly shows. This corolla pattern is typical of $V$. dasyphylla (Fig. 3). On the other hand, when present, darker lines on $V$. cotyledon are relatively inconspicuous (Watson $\&$ Flores 2007), and its white-flowered forms almost lack venation completely (Fig. 10).
Curiously, instead of providing any further reason or justification for the relationship with $V$. cotyledon, Becker went on to make the following informal comparative observation based on $V$. dasyphylla directly after the relevant type descriptions: " $V$. dasyphylla and $V$. cotyledon subsp. lologensis exhibit points of strong resemblance. Both have small flowers with completely glabrous petals and shorter spurs. V. cotyledon has the most strongly hairy petals ..."

Given that comment, the decision to ally his subsp. lologensis with $V$. cotyledon rather than $V$. dasyphylla would seem potentially untenable.

Considering it was based entirely on the protologue and comments as quoted above (Becker 1928), the placement by Rossow (1988) of subsp. lologensis in synonymy with $V$. dasyphylla was logical and practical. He had no extensive personal knowledge of the section, or opportunity to view the specimens at Kew (Rossow 1988), and the taxon was unknown in habitat to anyone but Comber himself, who died in 1969 (Coats 1970).

As noted, Comber, also an accomplished photographer, was sponsored by British gardeners (Coats 1970, Del Vitto 1998). As a result various attractive plants he encountered have long been better known to lay specialists than to botanical science. Sampson Clay (1937) produced a supplement to an earlier encyclopaedic horticultural survey of the world's mountain flora. He approached plant explorers for information and illustrations. They included Comber, whose 
black and white photograph captioned subsp. lologensis, the only reliably identified image of the taxon, is included in his work (Clay 1937: plate 55), and is also reproduced here (Fig. 9). Despite technical limitations, it clearly reveals the plant's critical characteristics, including the calyx.

Extensive familiarity with $V$. cotyledon and $V$. dasyphylla in their habitats at numerous sites has led to relatively facile differentiation between these species in the sterile state on most occasions. Foliage of $V$. dasyphylla may be seen in Figures $3 \& 4$, that of $V$. cotyledon in Figures $10 \& 11$. Even when most alike, a combination of the characters as follow will almost invariably determine them:

\section{Key to Distinguish $V$. COTYLEDON AND $V$. DASYPHYLLA By FOLIAGE}

1. Axil of shoot clearly elongated, rosette imbricate on face only, leaves arranged laxly below. Blade lanceolate or oblanceolate to spathulate

1'. Rosette closely imbricate throughout, compact and depressed, axis of shoot abbreviated. Leaf blade broadly subspathulate to spathulate.

2. Rosette always as above. Rosettes of plant closely proximate, contingent. Foliage always green or bronze-green. Leaf distinctly apiculate. Cartilaginous leaf margin green or dull reddish, never white or pale yellow.............. dasyphylla

2'. Rosette very rarely as above. If so, then rosettes of plant usually in loose and uneven formation. Foliage most commonly green, at times glaucous. Leaf as a rule less or not apiculate. Cartilaginous margin of leaf frequently white or pale yellow

V. cotyledon

These characteristics are also well depicted for $V$. dasyphylla in Watson (1994b: plate 334, incorrectly captioned as Viola fluehmannii Phil.), and for $V$. cotyledon in Watson \& Flores (2007). Ferreyra et al. (2006) observe in their text: " $(V$. dasyphylla) ... rosettes dense, cylindrical or hemispheric." and "It can be recognised by its low rosettes, camouflaged against the ground ..."

Another important floral distinction has apparently escaped the attention of other trained observers. In the live state at anthesis the calyx of $V$. dasyphylla is shinyviscid and commonly jet-black, or at least almost always deep-toned (Figs 3 \& 4). Erskine (1994) notes that on Cerro Colohuincul, "In some instances the flowers (of $V$. dasyphylla) had striking reddish calyces ..." However, although sometimes evident in habitat photographs, as in examples cited above, this condition is scarcely if at all perceptible in dry voucher specimens. It is also usually obscured, even in habitat, due to the calyx being mainly or entirely concealed beneath the foliage. By contrast, the calyx of $V$. cotyledon is never black or dark red, but more or less green-herbaceous to pale yellow or whitish, subviscid, and readily visible as a rule (Figs $10 \& 11$ ).

Examination of Comber's $V$. lologensis collections at Kew and his photograph cited above reveal it to have notably elongated shoots sparsely clad with foliage in the lower section and terminated by lax rosettes: Clay (1937) confirms this habit in his comparison with typical $V$. cotyledon. The calyx of $V$. lologensis is pale; the leaves equate to the narrower blade outline of $V$. cotyledon. Without doubt, this Lolog plant always, evidently and uniquely combines critical characters which are otherwise limited either to $V$. dasyphylla or $V$. cotyledon. Furthermore, Comber describes both Lolog populations as having distinctive foliage: "Whole plant tinged purplish" (type), "Leaves purplish" respectively (Comber 1928). Thus, several diagnostic features consistently distinguish the taxon in question from nearest relatives, urging elevation of $V$. cotyledon subsp. lologensis to species rank. Its circumscription and recognition at that taxonomic level conforms to many similar narrowly defined species within sect. Andinium.

\section{DiFFERENTIATING KEY FOR $V$. COTYLEDON, DASYPHYLLA AND LOLOGENSIS}

1. Flowers large, over $1.5 \mathrm{~cm}$ wide, lowermost and lateral petals always clearly bearded ....................... cotyledon

1 '. Flowers medium, under $1.5 \mathrm{~cm}$ wide, all petals glabrous.

2. Rosettes always depressed, distinctly imbricated, often somewhat cryptically coloured. Leaves more or less spathulate. Calyx at anthesis shiny-viscid, usually dark, usually jet-black V. dasyphylla

2'. Rosettes lax, elongated, not tightly imbricated, purplish. Leaves oblanceolate. Calyx pale. V. lologensis

Specimen eXamined: "Hill near Vega Lolog, 1380 m., Dec. 1926, H.F. Comber 553; Perennial with long taproot, from sandy hilltop. Leaves purplish. Flowers white with blue lines and yellow eye." (K!). 


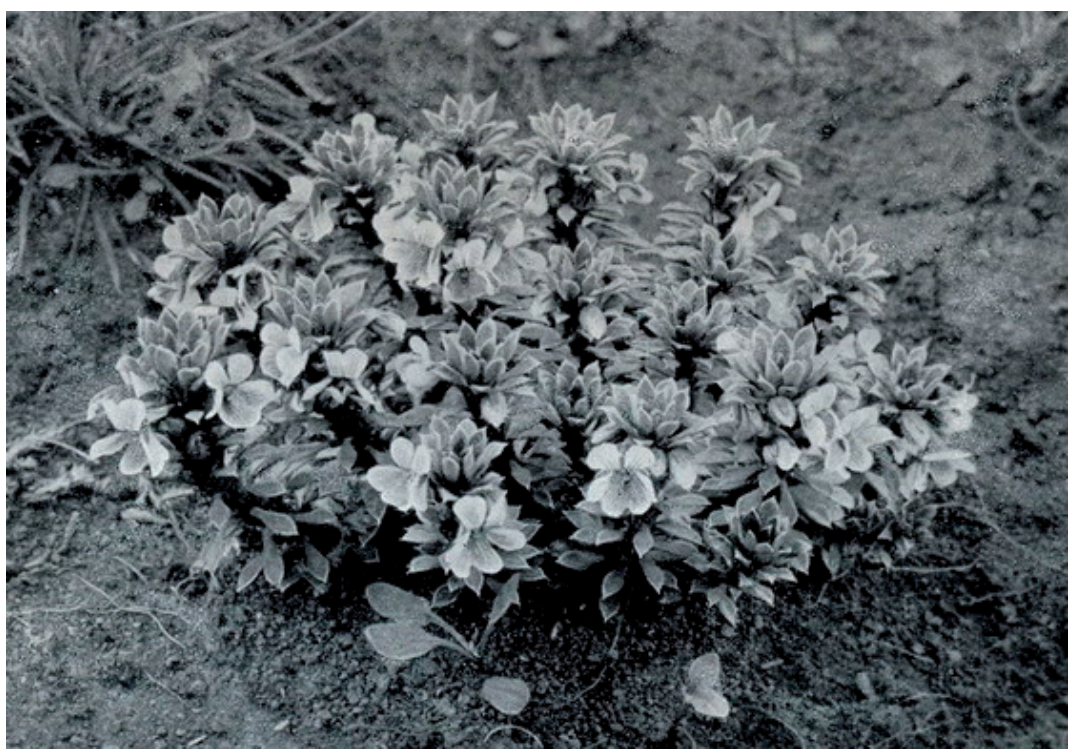

Figure 9. Viola lologensis (W. Becker) J.M. Watson, Lago Lolog, Neuquén, Argentina, December 1926 (Photo: Harold Comber, reproduced from Clay, 1937)

Figura 9. Viola lologensis (W. Becker) J.M. Watson, Lago Lolog, Neuquén, Argentina, diciembre 1926 (Foto: Harold Comber, reproducido desde Clay, 1937)

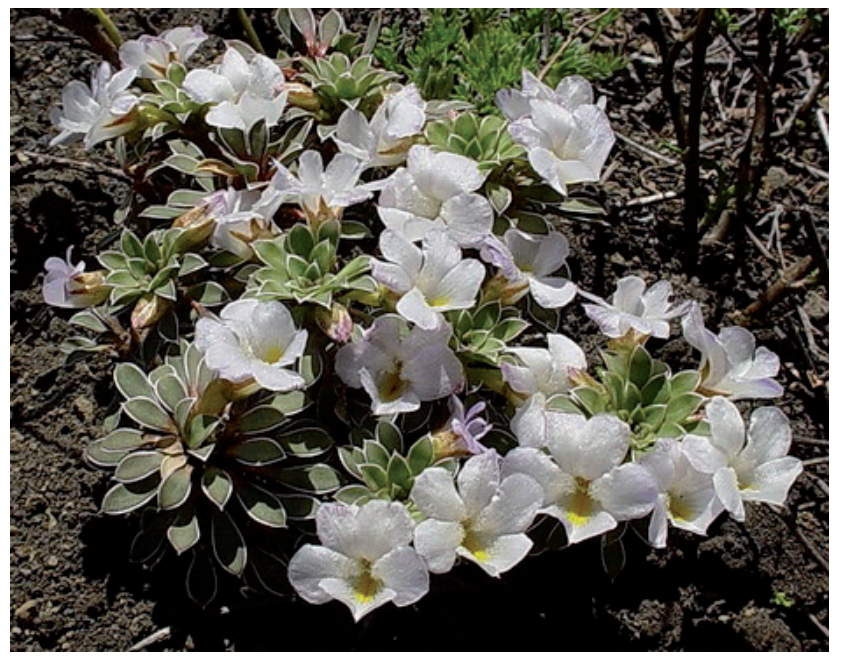

FiguRE 10. A white-flowered Viola cotyledon with the usual muchreduced guidelines. The narrower foliage and lax form are also apparent. Lonquimay Pass, Chile, November 2003 (Photo: Ana Flores).

FIGURA 10. Flores blancas de Viola cotyledon con la casi ausencia de líneas en los pétalos. También se aprecia la forma laxa y angosta del follaje. Paso Lonquimay, Chile, noviembre 2003 (Foto: Ana Flores).

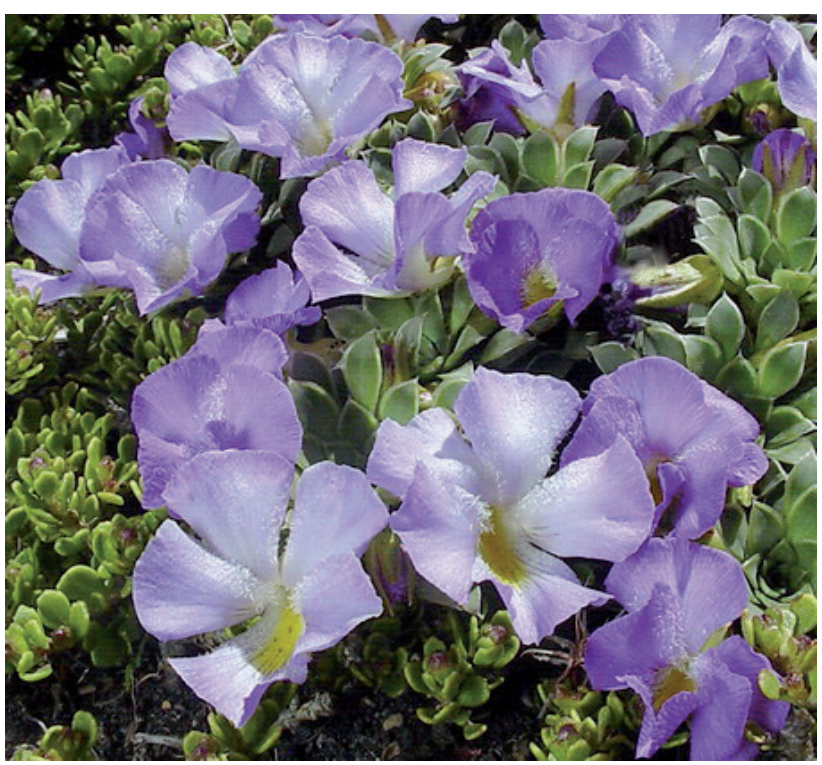

Figure 11. V. cotyledon. Volcán Lonquimay, Chile, November 2003 (Photo: Ana Flores).

Figura 11. V. cotyledon Volcán Lonquimay, Chile, noviembre 2003 (Foto: Ana Flores). 
Viola nobilis W. Becker, Bot. Jahrb. Syst. 37: 590. 1906. TYPE: "Peru, (Dept. Junín): auf Bergen westlich von Huacapistana in voller Blüte gesammelt. Auf Steppen mit eingestreuten Sträuchern, $3200 \mathrm{~m}$ ü. M., blühend am 18 Januar 1903, Weberbauer 2214" (lectotype, designated here, $\mathrm{Z}$ not seen*, holotype B destroyed).

*Note: Not seen by the present authors, but examined by H.E, Ballard jr., who provided the information.

Much herbarium material was eliminated during the allied bombing of Berlin in March 1943 (Hagemann \& Zepernick 1993), including the holotype of V. nobilis (Liesner 1993). At the time Liesner wrote, the holotype was presumed to have been the only specimen, but Prof. H.E. Ballard has since discovered an isotype at Zürich, and has generously offered the opportunity for it to be lectotypified in this paper.

\section{DISCUSSION}

\section{Viola comberi}

Clearly, the number and incompatible nature of variations between their several organs indicate beyond doubt that $V$. comberi cannot reasonably be dismissed as an aberrant or monstrose form of $V$. coronifera.

While possible, random hybrid origin seems improbable. Hybrids in the section are now recognised but rare (Watson, Blaxland \& Flores unpubl.). However those identified or suspected have been intermediate between actual or postulated parents, with no dissociated characters. If hybrid origin is insisted upon, $V$. coronifera (Fig. 5) must be one hypothetical parent and $V$. dasyphylla (Figs $3 \& 4$ ) is the only credible second parent on Colohuincul for reasons of morphology and habitat proximity. A shared pollinator between species possessing such dissimilar corollas seems implausible. Interim evidence and observations strongly support the probability for Andean violas of at least partial specialised pollinator selection based on colour, scent, style crest and spur morphology, as well as altitudinal distribution (Watson 1994a, Watson \& Flores 2007, Watson \& Flores unpubl.)

However, if the hypothesis is considered, an explanation is required for the pilose stamens of $V$. comberi, a rare, perhaps derived feature recorded for no other species on the mountain and relatively few taxa in the section. Unfortunately the collector did not note whether $V$. comberi was found close to any other Viola species (Comber 1928). Viola seeds are relatively heavy and can only be expelled short distances by natural ballistics or ants (Yoo \& Jang 2010). So proximity to at least one parent would be expected if hybrid origin were recent, as suggested by the existence of a solitary example with a single rosette.

To encounter sect. Andinium populations of extremely few individuals, or even a single plant, is not exceptional (pers. obs.). Despite being known to date as one example, we therefore consider that on the basis of several consistent differences from its relatives, this enigmatic but preciselydescribed taxon merits recognition at the species level. Considering any prospective search to locate further possible individuals of $V$. comberi in habitat, the facies of $V$. coronifera and $V$. comberi appear to be so equivalent that distinction between them under field conditions may not prove possible. In that case large-scale comparison would need to be carried out later with adequate dissection and magnification facilities. As one potential future line of investigation therefore, a systematic programme to collect a considerable random sample of corollas, one per plant, of these yellow violas on Colohuincul is recommended. This should include all brown-veined individuals. It could provide critical insight into the alternative possibilities of the existence of further individuals of $V$. comberi, or hybridisation, or floral variation in $V$. coronifera .

Inaccessible-looking Cerro Curruhue $(2,130 \mathrm{~m})$ immediately opposite to the north above Lago Curruhue Grande may also harbour related populations of these violas.

If never encountered again, and considering its close similarity to $V$. coronifera, the origins, status and distribution of $V$. comberi will remain open to speculation.

Why did Rossow (1988) place $V$. comberi in synonymy with $V$. cotyledon? They differ so radically in flower size, posture, colour and relative spur proportion, as well as leaf-blade outline. Other contemporary authors have either considered it a form or synonym of $V$. coronifera (Watson 1994a, 1994b), or a distinct species (Watson \& Flores 2007). Following the $V$. cotyledon entry, Rossow (1988) observed that although he had not seen the $V$. comberi type specimen, his synonomy was based on careful study of its description. As a result he had found no significant difference between $V$. cotyledon and $V$. comberi other than the yellow corolla and indumentum on the upper petals of the latter. $\mathrm{He}$ supposed the exceptional flower colour might have been an abnormality of that particular plant, or else a descriptive mistake by Comber. Rossow then cited an otherwise typical V. cotyledon (M.N. Correa et al. 5716) with similarly pubescent petals for comparison. There is no reason at all to doubt Comber's colour description of the corolla (Comber 1928). Rossow (1988) also had difficulty with $V$. coronifera, which he mistakenly described as white. Comber correctly recorded it as yellow (Comber 1928, Becker 1928). Becker (1928) in fact described glabrous upper petals for V. comberi in the protologue, with clavate indumentum on the lateral petals only, exactly equivalent to his circumscription of $V$. coronifera. Rossow's comparative reference to an atypical specimen of $V$. cotyledon is therefore irrelevant.

Among other critical omissions from Rossow, are lack of comparisons between flower sizes and positions. Becker (1928) notes $V$. comberi flowers as about $1 \mathrm{~cm}$ wide and 
"subconspicui". As with $V$. coronifera they form a usually upwards-facing crown or ring on the rosette face (Fig 5). By contrast, flowers of $V$. cotyledon measure ca $1.5-2 \mathrm{~cm}$ or more across, among the largest of the section, and are showy, even in sicco. They also always face more or less obliquely outwards clearly at or below the rosette circumference, and as a rule much more randomly (Figs $10 \& 11$ ). Furthermore, the impeccable standard of the collector Comber's fieldwork and supporting descriptions are apparent to all who study his work (e.g. N.M. Correa pers. comm.). However, Comber recorded his $V$. coronifera type collection from $2500 \mathrm{~m}$ on Colohuincul (Becker 1928). This exceeds the highest point of the U-shaped massif by $124 \mathrm{~m}$, so, as an exception, Comber's elevation data should not be regarded as closely accurate.

Rossow related in 1993 how he had attempted to explore Colohuincul before contributing Viola to Flora Patagonica, but failed to reach high elevations and had seen no yellowflowered violas (R.A. Rossow pers. comm.). He also recognised he had misinterpreted and omitted taxa in his Flora Patagonica treatment. He made clear to the present authors that he intended to revise his work, but sadly did not live to do so.

\section{Viola escondidaensis}

The Tromén Park entrance is situated at 2,000 m Valle Escondida and the El Huecú $(1,700 \mathrm{~m})$ site, although both marginally lower in elevation, are also mountainous Andean. By contrast, the Pilcaniyeu site lies out on the steppe plains at $980 \mathrm{~m}$. It is included in an informal Bergen University website entry (Ecological and Environmental Change Research Group undated). The report outlines an investigative visit in 2005. Despite the location's relatively lower elevation, the following cushion chamaephytes were recorded among the associated flora: Azorella trifurcata (Gaertn.) Pers., Colobanthus lycopodioides Griseb., Junellia patagonica (Speg.) Moldenke, J. tridactylites (Lag.) Moldenke, Nassauvia juniperina Skottsb. and $N$. lagascae (D. Don) F. Meigen. P.J. Erskine (in litt.) notes $V$. escondidaensis at Pilcaniyeu as a population spread over about 40m, amongst open low bushes and rather sparse groundcover. The Tromén Park habitat consists of superficially loose sandy-soiled slopes, or open, shallow depressions, always with a more or less continuous cover of dominant and widespread, well-grazed bunchgrass (Fig. 7). $V$. escondidaensis has only been found there in and between the bunchgrasses.

Familiarity with the Tromén habitat indicates the species as a probable recent steppic ecotype adaptation, able to elude or survive potentially lethal grazing by regenerating vigorously from below ground and sheltering among more resistant vegetation such as bunchgrass. Another plausible hypothesis might be selective specialised morphology for surviving burial by frequent dense ash layers carried and spread by the prevailing westerly winds during explosive
(Plinian) Andean volcanism. Over the last 40 years alone this phenomenon has occurred within the distribution range of $V$. escondidaensis as a result of eruptions by the volcanoes Villarica (1971), Lonquimay (1988), Copahue (2000), Llaima (2008) and the Puyehue-Caulle range (2011). Within the same period massive deposits have been produced further south by the Hudson (1991) and Chaitén (2009) eruptions.

Except for its white, few-lined flowers the southern colony of $V$. escondidaensis (Fig. 8) corresponds closely with Comber's prominently white-hispid type. The markedly glabrescent tendency of the most northern population (Figs $6 \& 7$ ) may be regarded as perhaps representing the early stage of a not untypical linear Andean evolution.

The paper containing the detailed description of $V$. escondidaensis (Becker 1928) provided data on other taxa of the genus for Rossow (1988). His failure even to mention the species in that work must therefore seem inexplicable. He gave a reason shortly before his untimely death. In the first place he was unable to examine the type, then the only extant material. Although clearly very atypical and systematically remote from all others in Patagonia, V. escondidaensis could have been known already as an obscure extra-Argentinian taxon. He therefore concluded that full investigation in the literature was essential. Unfortunately there was insufficient time to evaluate or add the species before publication (R.A. Rossow pers. comm.). Ironically, Rossow himself, together with colleagues, was the next collector. That chance discovery at Tromén in 1992 led directly to its location at the same site by the present authors a decade later. Consequently it was included in our dissertation at the 2005 Vienna International Botanical Congress, and also featured in a review of sect. Andinium in Chile (Watson \& Flores 2007).

This confused situation has apparently caused later repercussion in Argentinian botany. The Viola treatment in Flora Patagonica (Rossow 1988) forms a key reference in Argentina, although in fact he was not given sufficient preparatory time to familiarise with the genus (M.N. Correa pers. comm.). Recent authors have evidently encountered $V$. escondidaensis equally validly published in the same Becker (1928) paper as are eight other taxa included by Rossow. They must therefore conclude it cannot be an accepted element of the Patagonian flora. Instead it appears in synonymy under Viola fluehmannii Phil. for current Argentina-based taxonomic listings (Xifreda \& Sanso 1999, Sanso et al. 2008). Even without reference material however, the detailed and precise circumscriptions of $V$. escondidaensis and V. fluehmannii by Becker (1928) and Philippi (1892) respectively plainly indicate many wide and incompatible differences between the species. Among their more evident distinctions can be mentioned rhizomatous growth, presence of indumentum and absence of stipules in $V$. escondidaensis, and the opposite for $V$. fluehmannii, including its subwoody shrublet life-form. The totally 
disparate habits and appearance of the two species may be appreciated by direct comparison of Figures $6,7 \& 8$ here with figs $4 \mathrm{a}$ and $4 \mathrm{~b}$ in Watson \& Flores (2007).

\section{Viola lologensis}

In late 2007 the authors devoted several days to searching for $V$. lologensis in the wild. The first stage consisted of pin-pointing the original sites collected by Comber (1928), whose names have since become unknown to the majority of local inhabitants. Once definitively located, those regions were explored fairly exhaustively at the elevations noted by Comber. No Viola species were encountered. $V$. lologensis may only be relocated by local botanists, if at all.

The areas where Comber collected $V$. lologensis consist of high ground just to the east of Lago Lolog, and north of its eastern end (Fig. 1). He apparently found it while trekking on horseback (Woodward 1973) to Cerro Colohuincul from San Martín de los Andes (Comber 1928).

A likely hypothesis for the evolution of $V$. lologensis, based on morphology and known phytogeography, suggests established hybrid origin, with $V$. cotyledon and $V$. dasyphylla as putative parents. Both the latter species occur on Cerro Colohuincul shortly to the north of Lago Lolog. $V$. dasyphylla also inhabits the summit area of Cerro Colorado, immediately south of the lake (pers. obs.). However, as long as hybrid origin remains hypothetical rather than evidential, it is more appropriate to regard $V$. lologensis as a species rather than a stable nothospecies, as defined by Article 3.4 in McNeill et al. (2006).

\section{CONCLUSION}

Section Andinium is exceptional for the lack of information and/or extreme rarity associated with a very significant number of its taxa. Some reasons for this phenomenon are offered in Watson \& Flores (2007), who provide illustrations and notes of two typically rare examples, the Chilean endemics, Viola minutiflora Phil. and Viola ovalleana Phil., as well as a brief mention of $V$. comberi. In addition, the red data book of the Coquimbo Region (Marticorena et al. 2001) cites $V$. ovalleana as "IC(EX?)" (Insufficiently known, possibly extinct) in its conservation assessments. A further Argentinian example of extreme endemic rarity is presented by recently described Viola exsul J.M. Watson \& A.R. Flores (Rossow et al. 2003), known only from the type site and not revisited since the type collection (R. Kiesling pers. comm.). Peruvian V. nobilis (lectotypified above) is only recorded by the type gathering made early in the last century. Its presence in the wild has not been reconfirmed since (Liesner 1993).

The disadvantageous factors revealed above, which obstruct a clear understanding of these species, must also be taken in conjunction with the section's traditional taxonomic boundaries, as broadly retained up to the present. They are at times based on floral microfeatures, which may only become apparent after dissection and/or magnification. Such features are often not evident at casual sight to the naked eye, either in living plants or herbarium specimens (Watson \& Flores 2007).

Because of these combined difficulties, exhaustive studies allied to extensive fieldwork and sufficient experience of the section are essential as a fundamental basis for a definitive overview and for presenting authoritative judgements, including publication of new taxa. Accordingly, in the absence of this vital preparatory comprehension and accumulated insight we strongly advise against altering complex published results and opinions of original taxon authors or other acknowledged specialists. As a corollary, when well-considered changes are made, it is recommended they be accompanied by careful justifications.

\section{ACKNOWLEDGEMENTS}

Critical unpublished data on the fieldwork of her father was copied from her personal files by Mary Comber-Miles. Martin and Anna Sheader provided valuable, prompt input and comparative illustrations. Peter Erskine and other interested Alpine Garden Society members as cited in text have also added to our knowledge of these violas. Manuel Millahuinca kindly directed us to the original Rossow site of $V$. escondidaensis. Fieldwork contributing to the investigation of $V$. lologensis formed part of a larger project generously financed by the Alpine Garden Society, Pershore, United Kingdom. As noted above, Prof. Harvey Ballard of Ohio University unselfishly offered the opportunity to publish a result of his own research. He and the other main reviewers also made many valuable improving suggestions.

\section{REFERENCES}

Becker, W. 1925. Viola. In: H.G.A. Engler \& H. Melchior (eds.), Die natürlichen Pflanzenfamilien 2a ed. 21: 363-377.

Becker, W. 1928. On some violets from the Andes. Bulletin of Miscellaneous Information, Royal Botanic Gardens, Kew, 1928: 133-140.

Clay, S. 1937. Viola. In The present-day rock garden. T.C. \& E.C. Jack, London \& Edinburgh. 691 pp., 56 plates.

CoAts, A.M. 1970. The Plant Hunters. McGraw-Hill, New York. $400 \mathrm{pp}$.

Comber, H.F. 1928. Andes expeditions 1925-6 and 1926-7. Field notes of plants collected by H.F. Comber. Constable, Edinburgh. 82 pp.

Del Vitto, L.A., E.M. Petenatti \& M.N. Correa. 1998. Evolución del conocimiento botánico de la Patagonia Argentina. 6.11. Colecciones menores y otras contribuciones. En: N.M. Correa (ed.), Flora Patagónica, parte 1: 197-198. INTA, 
Buenos Aires.

Ecological and Environmental Change Research Group. Undated. Northern Patagonia. www.eecrb.uig.no/.../ NorthernPatagonia/htm Viewed 14 April 2011.

Erskine, P.E. 1994. With the AGS in the Andes. Patagonia, 1992. Bulletin of the Alpine Garden Society 62: 291-292.

Ferreyra, M., C. Ezcurra \& S. Clayton. 2006. Flores de alta montaña de los Andes patagónicos. "High Mountain Flora of the Patagonian Andes". Editorial L.O.L.A., Buenos Aires.

Hagemann, I \& B. Zepernick (eds). 1993. On the history of the Berlin Botanic Garden. In The Berlin-Dahlem Botanic Garden. The Berlin Botanic Garden Fördererkreiss der naturwissenschaftlischen Berlins e.V. 112 pp.

Liesner, R.L. 1993. Viola. In: L. Braco \& J.L. Zarucchi (eds.), Catalogue of the flowering plants and gymnosperms of Peru: 1182-1184. Missouri Botanical Garden Press.

Marticorena, C. \& M. Quezada. 1985. Catálogo de la flora vascular de Chile. Gayana Botánica 42(1-2): 1-157.

Marticorena, C., F.A. Squeo, G. Arancio \& M. Muñoz. 2001. Catálogo de la flora vascular de la IV Región de Coquimbo. En: F.A. Squeo, G. Arancio \& J.R. Gutiérrez (eds.), Libro rojo de la flora nativa y de los sitios prioritarios para su conservación: Región de Coquimbo, 105-142. Universidad de La Serena.

McNeill, J., F.R. Barrie, H.M. Burdet, V. Demoulin, V.L. Hawksworth, D.H. Nicholson, J. Prado, P.C. Silva, J.E. Skog, J.H. Wiersma \& N.J. Turland. 2006 International Code of Botanical Nomenclature (Vienna Code). Gantner Verlag, Ruggell, Liechtenstein. 568 pp.

PhiLIPPI, R.A. 1892. Plantas nuevas chilenas de la familia Violáceas. Anales de la Universidad de Chile 81: 346.

ReICHE, C. 1893. Violae chilenses. Ein Beitrag zur Systematik der
Gattung Viola, Botanische Jahrbücher für Systematik, Pflanzengeschichte und Pflanzengeographie 16: 405-452, 2 plates.

Rossow, R.A. 1988. Violaceae. En: N.M. Correa (ed.), Flora Patagonica, parte 5: 170-189. INTA, Buenos Aires.

Rossow, R.A., J.M. Watson \& A.R. Flores. 2003. Viola. En: R. Kiesling (ed.), Flora de San Juan 2: 139-146. Estudio Sigma, Buenos Aires.

Sanso, A.M., C.C. Xifreda \& M.N. Seo. 2008. Viola. En: F.O. Zuloaga, O. Morrone \& M.J. Belgrano (eds.), Catálogo de las plantas vasculares del Cono Sur (Argentina, Sur de Brasil, Chile, Paraguay y Uruguay) Vol. 3 - Dicotyledoneae: Fabaceae (Senna-Zygia) - Zygophyllaceae: 3158-3169. Missouri Botanical Garden Press.

WAtson, J.M. 1994a. Viola. South American alpines. Bulletin of the Alpine Garden Society 62: 327-342.

WATSON, J.M. 1994b. Viola coronifera, Viola dasyphylla \& Viola escondidaensis. In: K.A. Beckett (ed.), Alpine Garden Society encyclopaedia of alpines, vol. 2: 1379-1382; Plate 534. Alpine Garden Society, Pershore, United Kingdom.

Watson, J.M. \& A.R. Flores. 2007. Violas rosuladas en la flora de Chile. Chagual 5: 33-47.

Woodward, R. 1973. H.F. Comber and plants of the Andes. Bulletin of the Alpine Garden Society 41: 98-121.

Xifreda, C.C. \& A.M. SAnso. 1999. Viola. En: F.O. Zuloaga \& O. Morrone (eds.), Catálogo de las plantas vasculares de la República Argentina 2: 1173-1177. Missouri Botanical Garden Press.

Yoo, K.-O. \& K.-S. JANG. 2010. Infrageneric relationships of Korean Viola based on eight chloroplast markers. Journal of Systematics and Evolution 48(6): 474.

Zwienen, K.J. van. 2011. Viola coronifera, Cerro Colo-huincul. Keesjan.smugmug.com/...and.../Patagonia.../801688304_ XckRM Viewed 4 May 2011.

Recibido: 26.08.09

Aceptado: 16.08.11 